\title{
Türkiye’de Dernek Yöneticilerinin Sosyal Güvenliği ve Güveni Kötüye Kullanma İkilemi
}

\section{Dr. Öğr. Üyesi Mehmet Bulut ${ }^{1^{*}}$}

Geliş tarihi: 02.12.2019

Kabul tarihi: 18.12.2019

\section{Atıf bilgisi:}

IBAD Sosyal Bilimler Dergisi

Sayı 5 Sayfa: 645-655

Yıl: 2019 Dönem: Güz

This article was checked by iThenticate. Similarity Index 29\%

\footnotetext{
1 Bayburt Üniversitesi İktisadi ve İdari Bilimler Fakültesi Maliye Bölümü, Türkiye, mehmetbulut@bayburt.edu.tr,
} ORCID ID 0000-0003-0157-4906
ÖZ

Dernek kurma, Anayasa ile güvence altına alınmış kişisel haklar arasında yer almaktadır. Türkiye'de dernek yöneticilerinin sigortalılığı konusunda yasal bir boşluk bulunmaktadır. Bu konu Sosyal Güvenlik Kurumu tarafindan çıkartılan Genelge ile açığa kavuşturulmuştur. Buna göre, dernek yöneticileri, bu göreve seçimle geldiklerinden, aralarındaki hukuki ilişki de vekalet akdine dayandığından sigortalı sayılmamaktadırlar. Ancak dernek yöneticileri, bu görevleri haricinde, hizmet akdine tabi olarak, üçüncü şahısların yapabilecekleri işleri yapmaları karşılığında ücret ödenmesi şartıyla 5510 sayılı Kanun (4/a) kapsamında sigortalı sayılmaktadırlar. Bununla birlikte, dernek yöneticilerinin dernek bütçesinden aldıkları bazı ödemeler Dernekler Kanunu ve Türk Ceza Kanunu uyarınca güveni kötüye kullanma suçu olarak nitelendirilebilmektedir. Dolayısıyla ortada bir ikilem bulunmaktadır. Ancak Yargitay kararları dernek yöneticilerine yapılan ödemeleri, gerçeği yansıtması ve bir hizmet karşılığı olması şartıyla, güveni kötüye kullanma kapsamında saymamaktadır. Bu noktada özellikle kamu görevlisi kavramının tayini ve yapılan ödemenin sebebi önem taşımaktadır.

Anahtar Kelimeler: Dernek, Dernek yöneticisi, Sosyal güvenlik, Güveni kötüye kullanma

*Sorumlu yazar 


\title{
In Turkey Social Security of Association Managers and the Dilemma of Abuse of Trust
}

\author{
Assist. Prof. Dr. Mehmet Bulut ${ }^{1^{*}}$
}

First received: 02.12 .2019

Accepted: 18.12.2019

\section{Citation:}

IBAD Journal of Social Sciences

Issue: $5 \quad$ Pages: 645-655

Year: 2019 Session: Fall

This article was checked by iThenticate. Similarity Index 29\%

1 Bayburt University Faculty of Economics and Administrative Sciences, Department of Finance, Turkey, mehmetbulut@bayburt.edu.tr,

ORCID ID 0000-0003-0157-4906

\section{*Corresponding Author}

\begin{abstract}
Establishment of an association is among the personal rights guaranteed by the Constitution. There is a legal vacuum on subject of Social security of association managers in Turkey. This issue was clarified by the Circular issued by the Social Security Institution. According to this circular, association managers are not considered insured. Because the association managers come to this duty by election and the legal relationship between them is based on the power of attorney agreement. However, if the managers of the associations work in the works that third parties can do and the wages are paid, they are considered insured under the Law No. 5510 (4/a). However, some payments received by association managers from the budget of the association may be considered as a crime of abuse of trust under the Law on Associations and the Turkish Penal Code. Therefore, there is a dilemma. However, the decisions of the Court of Cassation do not count the payments made to the managers of the association within the scope of abuse of trust provided that it reflects the truth and is in return for a service. At this point, the determination of the concept of public servant and the reason for the payment made are particularly important.
\end{abstract}




\section{GİRIŞ}

Anayasal bir hak olan ve serbestlik ilkesine dayanan dernek kurma, faydalarının yanı sıra beraberinde bazı yükümlülükleri getirmektedir. Özellikle dernek yöneticilerinin uymaları gereken önemli kurallar ve izlemeleri gereken bazı prosedürler bulunmaktadır. Bu kapsamda ortaya çıan yükümlülükler çoğu zaman kanunlar veya ikincil mevzuat ile doğrudan düzenlenmiş olmasına karşın, bazı hususların yüzeysel olarak düzenlendiği ve yoruma açık bir hüviyete sahip oldukları görülmektedir. Bu gibi durumlarda da uyuşmazlıkların ortaya çıkması kaçınılmaz olmaktadır. Ancak denetim raporları, yargı kararları ve bilimsel yorumlar (doktrin) vasıtasıyla söz konusu boşlukların doldurulması mümkün olabilmektedir.

Dernekler yürüttükleri faaliyetleri bazen üyeleri vasıtasıyla gerçekleştirmekte, bazen işçi çalıştırma yoluna gitmekte, bazen de yöneticiler işe dahil olmaktadırlar. Hatta derneklerin bünyesinde iktisadi işletmeler kurularak faaliyetler çeşitlendirilebilmektedir ${ }^{1}$. Bu noktada özellikle dernek çalışanların ve iş̧ gören dernek yöneticilerinin sosyal güvenliği bazı tereddütlere neden olabilmektedir. Nitekim hangi işlerin, nasıl ve ne ölçüde yapılabileceği hakkında mevzuatta bulunan genel ifadeler yasal yükümlülüklerin çerçevesini belirlemede sıkıntılara neden olmaktadır.

Bu çalışmamızda özellikle, çok fazla akademik çalışmalara konu edilmemiş olan, dernek yöneticilerinin dernek faaliyetlerinde görev almaları halinde sosyal güvenlik mevzuatı karşısındaki durumları ve Dernekler Kanunu ile Türk Ceza Kanunu'nda yer alan güveni kötüye kullanma suçu ikileminden bahsedilecek ve kurum uygulamaları ile yargı kararları bağlamında değerlendirmelerde bulunulacaktır.

\section{GENEL OLARAK DERNEK YÖNETİCILİĞİ}

Dernek sözcüğü Türk Dil Kurumu tarafından, "belirli ve ortak bir amacı gerçekleştirmek için kurulan yasal topluluk, cemiyet" olarak tanımlanmıştır (TDK, 2019). Bu tanımda ön plana çıkan en önemli iki husus; belirli ve ortak bir amacın varlığı ile yasal bir niteliğe sahip olunmasıdır. Dernekler toplumsal bazı ihtiyaçların çözüme kavuşturulması ve dayanışma maksadıyla kurulmuş tüzel kişiliklerdir. Nitekim tarih boyunca kişiler büyük sorunları çözebilmek için dayanışma gereksinimi duymuş ve toplumsal koşulların yarattığı zorunluluklar sonucunda da dernekler kurulmuştur (Yavuzyiğit, 1995, s. 416).

5253 sayılı Dernekler Kanunu ${ }^{2}$ ise 2 inci maddesinde derneği; kazanç paylaşma dışında, kanunlarla yasaklanmamış belirli ve ortak bir amacı gerçekleştirmek üzere, en az yedi gerçek veya tüzel kişinin, bilgi ve çalışmalarını sürekli olarak birleştirmek suretiyle oluşturdukları tüzel kişiliğe sahip kişi toplulukları olarak tanımlamışırı. 4721 sayılı Türk Medeni Kanunu da ${ }^{3}$ Dernekler Kanunu'nda yer alan hükme benzer bir şekilde dernek kavramını tanımlamışıır ${ }^{4}$.

Dernek kurma, Anayasa ile güvence altına alınmış kişisel haklar arasında yer almaktadır. Nitekim Anayasamızın 33 üncü maddesine göre; "Herkes, önceden izin almaksızın dernek kurma ve bunlara üye olma ya da üyelikten çıkma hürriyetine sahiptir. Hiç kimse bir derneğe üye olmaya ve dernekte üye kalmaya zorlanamaz. Dernek kurma hürriyeti ancak, millî güvenlik, kamu düzeni, suç işlenmesinin önlenmesi, genel sağlık ve genel ahlâk ile başkalarının hürriyetlerinin korunması sebepleriyle ve kanunla sinırlanabilir."

5253 sayılı Kanun'un 3 üncü maddesi ise dernek kurmada serbestlik ilkesine değinmiştir. Buna göre, fiil ehliyetine sahip gerçek veya tüzel kişiler, önceden izin almaksızın dernek kurma hakkına sahiptir ${ }^{5}$. Her uluslararası ve ulusal mevzuatlarda yer bulan derneklerin varlığı insanın insan olarak vazgeçemeyeceği ve her daim ihtiyaç duyacağı bir insan topluluğudur (Ecer, 2017, s.43).

\footnotetext{
15520 sayılı Kurumlar Vergisi Kanununda derneklerin kurduğu iktisadi işletmeler derneğe ait veya bağlı olup faaliyetleri devamlı bulunan ve sermaye şirketi ve kooperatifler dışında kalan ticari, sınai ve zirai işletmeler ile benzer nitelikteki yabancı işletmeler, dernek iktisadi işletmeleri olarak tanımlanmıştır.

2 Yayımlandığı Resmî Gazete: Tarih: 23/11/2004 Sayı: 25649.

3 Yayımlandığı Resmî Gazete: Tarihi: 8/12/2001 Sayı: 24607.

4 Dernekler, gerçek veya tüzel en az yedi kişinin kazanç paylaşma dişında belirli ve ortak bir amacı gerçekleştirmek üzere, bilgi ve çalışmalarını sürekli olarak birleştirmek suretiyle oluşturdukları, tüzel kişiliğe sahip kişi topluluklarıdır. (4721 SK, md.56)

5 Bu kuralın istisnası için bkz: 5253 savılı Kanun’un 3 üncü maddesi.
} 
Dernek yönetimi ibaresi ise dernek organlarından olan yönetim kurulu ve denetim kurulunu ifade etmektedir. Söz konusu kurulların oluşumu, Türk Medeni Kanunu'nda düzenlenmiştir. Buna göre, yönetim kurulu, beş asıl ve beş yedek üyeden az olmamak üzere dernek tüzügünde belirtilen sayıda üyeden oluşur ve derneğin yürütme ve temsil organıdır; bu görevini kanuna ve dernek tüzüğüne uygun olarak yerine getirir (4721 SK, md.84 ve 85). Denetim kurulu ise üç asıl ve üç yedek üyeden az olmamak üzere dernek tüzügünde belirtilen sayıda üyeden oluşur ve denetleme görevini, dernek tüzügünde belirtilen esas ve usullere göre yapar; denetleme sonuçlarını bir raporla yönetim kuruluna ve genel kurula sunar (4721 SK, md.86). Kanunda yer alan hükümlerden de yola çıkarak dernek yöneticisi ibaresinden, dernek başkanının yanı sıra dernek yönetim kurulu üyeleri ile denetim kurulu üyelerini anlamak gerekmektedir. Bununla birlikte genel kurul üyelerinin, yönetimde görevli olmayan diğer dernek üyelerinin ve dernek üyesi olmayan çalışanların yönetici olarak kabul edilmemesi gerekmektedir.

Derneklerin faaliyetlerini nasıl ve kimlerin eliyle sürdürülebileceği de Kanun'da belirtilmiştir. Buna göre, dernek hizmetleri gönüllüler veya yönetim kurulu kararı ile göreve başlatılan ücretliler aracıllğıyla yürütülür. Ayrıca dernek yönetim ve denetim kurullarının kamu görevlisi olmayan başkan ve üyelerine ücret verilebilir. Bununla birlikte yönetim ve denetim kurulu üyeleri dışındaki üyelere ücret, huzur hakkı veya başka bir ad altında herhangi bir karşıllı ödenmesi de Kanun ile yasaklanmıştır. (5253 SK, md.13)

\section{DERNEK YÖNETİCILERİNIN SOSYAL GÜVENLİĞİ}

Sosyal güvenlik, kişileri sosyal riskler karşısında koruyan ve bu sebeplerle ortaya çıkan zararları ortadan kaldırma veya azaltma işlevini gören, Anayasa ile güvence altına alınmış, asli bir sosyal politika uygulamasıdır. Bu yönüyle, kişinin karşılaşması mutlak ya da muhtemel tehlikelerin sonuçlarına karşı kişiye bir gelir garantisi sağlamak suretiyle kişiyi muhtaç duruma düşme riskine karşı güvenlik altına almanın genel adıdır (Arıcı, 2015, s. 4). Sosyal güvenliğin en önemli unsurlarından birisi ise Kanun kapsamına girilmesi halinde zorunluluk ilkesinin geçerli olmasıdır. Başka bir deyişle, kişiler sigortalı olma hakkından vazgeçemezler ve bunun aksi yönündeki sözleşmeler geçersizdir.

Kimlerin sosyal güvenlik kapsamında oldukları 5510 sayılı Kanun'un 4 üncü maddesinde belirtilmiştir. Buna göre, genel bir açıklamayla, hizmet sözleşmesine tabi olarak çalışanlar, bağımsız çalışanlar ve kamu görevlileri sigortalı sayılmaktadırlar. Bununla birlikte aynı Kanun'un 5 inci maddesinde bazı sigorta kollarına tabi olanlar, $6 \mathrm{nc}$ maddesinde ise sigortalı sayılmayanlar tahdidi olarak sayılmışlardır. Sigortalılığın kapsamı ve bildirim yükümlülüklerine ilişkin olarak ayrıca, Sosyal Sigorta İşlemleri Yönetmeliği $i^{7}$ ve Sosyal Güvenlik Kurumu tarafindan yayınlanmış olan 2013/11 sayılı Genelge bulunmaktadır. Gerek 5510 sayılı Kanun'da gerekse de Sosyal Sigorta İşlemleri Yönetmeliği'nde sigortalılığın kapsamına ilişkin genel ifadelere yer verilmiş olup dernek yöneticilerinin sigortalılı̆̆ı ile ilgili doğrudan bir açıklama bulunmamaktadır. Bu husustaki boşluk 2013/11 sayılı Genelge ile doldurulmuştur.

2013/11 say1lı Genelge'de 2016/20 sayılı Genelge ile yapılan 1/9/2016 tarihli değişiklik ile dernek yöneticilerinin sigortalılığına ilişkin bazı düzenlemeler getirilmiştir. Bu düzenlemeye göre, dernekler ya da derneklerin kurduğu iktisadi işletmelerde çalışma gönüllülük esasına dayandığından dernek yönetim ve denetim kurulu üyeleri ile dernek üyeleri dernekte yaptıkları işler nedeniyle ücret alsalar dahi sigortalı sayılmayacaktır. Söz konusu düzenleme 24/04/2019 tarihine kadar uygulanmış, ancak 24/4/2019 tarihli ve 2019/9 sayılı Genelge ile radikal bir değişikliğe gidilmiştir.

Yapılan değişiklik sonucunda söz konusu Genelge'ye göre; dernek başkanları ile derneğin yönetim ve denetim kurullarına seçilenler, bu göreve seçimle geldiklerinden, aralarındaki hukuki ilişki vekalet akdine dayandığı için sigortalı sayılmayacaklardır. Bu görevlerinden dolayı huzur hakkı veya sair bir ad altında ücret almaları akdin niteliğini değiştirmeyecektir. Dolayısıyla dernek yöneticilerine yürüttü̈leri görev nedeniyle yapılacak ödemeler, hukuki ilişkinin niteliğini değiştirmeyecektir ve sigortalı sayılmalarını gerektirmeyecektir.

Ancak, dernek başkanları ile derneğin yönetim, denetim kurullarına seçilenler ve dernek üyeleri; bu görevleri haricinde, hizmet akdine tabi olarak, üçüncü şahısların yapabilecekleri işleri yapmaları

\footnotetext{
${ }^{6}$ Yayımlandığ Resmî Gazete: Tarih: 16/6/2006 Sayı: 26200
}

7 Yayımlandığı Resmî Gazete: Tarih: 12/5/2010 Sayı: 27579 
karş1lığında ücret ödenmesi şartıyla Kanun'un ${ }^{8} 4$ üncü maddesinin birinci fikrasının (a) bendi (4/a) kapsamında sigortalı sayılacaktır. Burada önemli olan kriter, dernek yöneticisi tarafindan üçüncü bir kişi tarafından yapılabilecek işin ifa edilmesi ve karşılığında da ücret alınmasıdır. Genelge ile getirilen bu kural, hizmet sözleşmesinin asli unsuru olan ama sigortalılığın asli unsurlarından (şartlarından) sayılmayan ücretin (Aday, 2017, s. 300), dernek yöneticilerinin sigortalılı̆̆ı açısından asli unsur olarak sayılmasına neden olmuştur'. Oysa ki İş Hukukunda ücret iş sözleşmesinin zorunlu bir unsurudur (Güzel vd., 2018, s.104).

Dolayısıyla sosyal güvenliğin asli kuralının aksine, dernek yöneticileri tarafindan üçüncü şahısların yapabileceği işler ücretsiz olarak ifa edilmesi halinde sigortalılık söz konusu olmayacaktır. Nitekim bu hizmet ücret karşlığında yapılmıyorsa, işi görmek isteyen kişinin gönüllü olarak (ücret almaksızın) iş görmesinde herhangi bir engel bulunmamaktadır ve gönüllük esasına dayanarak iş görüldügüne ilişkin bir sözleşmenin yapılması mümkündür (Benzer, 2018, s. 172). Ancak gönüllülük ve dernek faaliyetinin toplumsal boyutu sigortalılığı etkilemeyecektir. Kişi, kanunun sigortalı sayılmak için belirlediği duruma dahil olmakla kendiliğinden sigortalı olacaktır ve yapılmakta olan işin toplumsal boyutu, sosyal güvenlik ile ulaşılmaya çalışılan evrensel amacın gözardı edilmesine yol açacak gerekçelere dayanak yapılamayacaktır ${ }^{10}$. Ayrıca, sigortalılığın oluşumu yönünden çalışma olgusunun varlığı zorunludur ve fiili çalışma saptanmadıkça, sadece hizmet akdine dayanılması halinde sigortalılık söz konusu olamayacaktır ${ }^{11}$.

Ayrıca Genelge'de değinilmemiş bir husus olarak belirtmek gerekir ki dernek yöneticisi tarafindan üçüncü bir kişi tarafindan yapılabilecek işin ifa edilmesi ve karşılığında da ücret alınması durumunda dernek yöneticisi ayrıca başka bir işyerinde de 4/a kapsamında sigortalı olarak çalışıorsa, bu durum dernekten de sigortalı olarak bildirilmesine engel teşkil etmeyecektir. Nitekim bir kişi aynı anda birden fazla işyerinden 4/a kapsamında sigortalı olarak bildirilebilmektedir. Söz konusu dernek yöneticisinin aynı zamanda Kanun'un 4 üncü maddesinin birinci fikrasının (b) bendi (4/b) kapsamında sigortalı olmas1 halinde ise 4/a kapsamında sigortalı sayılması gerekmektedir. Dolayısıyla böyle bir durumda dernekteki faaliyeti sigortalılık açısından öne geçmektedir. Ancak, sigortalılık hallerinin çakışması nedeniyle 4/a kapsamındaki sigortalılığı esas alınanlar, yazılı talepte bulunmak ve Kanunun 82 nci maddesine göre belirlenen prime esas kazanç alt sınırı ve üst sınırına ilişkin hükümler saklı olmak kaydıyla, esas alınmayan sigortalılık statüsü kapsamında talep tarihinden itibaren prim ödeyebilirler ${ }^{12}$. Başka bir ifadeyle, dernek dışında 4/b kapsamında sigortalılığı bulunan dernek yöneticisi talep etmesi halinde 4/a kapsamındaki sigortalılığı tercih etmeyebilir.

2013/11 sayılı Genelge'de değinilmeyen ve önem arz eden bir başka husus ise kamu görevlileri tarafından kurulan derneklerdeki yöneticiler tarafından üçüncü bir kişi tarafından yapılabilecek işin ifa edilmesi ve karşıllğında da ücret alınması durumudur. Nitekim Dernekler Kanunu'nun 13 üncü maddesine göre, dernek yöneticilerine ücret şeklinde ödeme yapılabilmesi hususu sadece kamu görevlisi olmayanlarla sınırlı tutulmuştur. Dolayısıyla kamu görevlisi olan yöneticilere ücret ödenmesi söz konusu olamayacak ve bu sebeple de Genelge'de belirtilen sigortalılık durumu söz konusu olmayacaktır. Durum bu şekilde olmakla birlikte Genelge'de bu hususa değinilmemiş olmasının sebebi sigortalılık hallerinin çakışmasına ilişkin kuraldır. Çünkü kamu görevlisi olup Kanunun 4 üncü maddesinin birinci fikrasının

\footnotetext{
8 Bu başlık altında belirtilen "Kanun" ibaresi bundan böyle 5510 sayılı Kanunu ifade edecektir.

${ }^{9}$ Kişinin ücret almasa da çalışmasının sigorta kapsama alınması ile ilgili olarak bkz: Yrg. 21. HD.’nin, E. 2003/6057, K. 2003/7240 sayll Karar1; Yrg. HGK'nin, E. 2004/737, K. 2005/26 sayll Karar1; Yrg. 21. HD.'nin, E. 2003/6057, K. 2003/7240 sayll Karar1 Yrg. 10. HD.'nin, E. 2006/16493, K. 2007/4738 sayll Kararı.

${ }^{10}$ Yargitay Hukuk Genel Kurulu E. 2004/10-37, K. 2005/26 sayll ve E. 2004/10-76, K. 2005/25 sayll Kararları.

11 Yrg. 10. HD'nin, E. 2015/22094, K. 2016/915 sayll Karar1.

${ }^{12}$ Sigortalının 4 üncü maddenin birinci fikrasının (a) ve (b) bentlerinde yer alan sigortalılık statüleri ile (c) bendinde yer alan sigortalılık statüsüne aynı anda tabi olacak şekilde Kanun kapsamına girmesi halinde öncelikle aynı maddenin birinci fikrasının (c) bendi kapsamında, (a) ve (b) bentlerinde yer alan sigortalılık statülerine tabi olacak şekilde Kanun kapsamına girmesi halinde ise aynı maddenin birinci fikrasının (a) bendi kapsamında sigortalı sayılır. Ancak, sigortalılık hallerinin çakışması nedeniyle Kanunun 4 üncü maddesinin birinci fikrasının (a) bendi kapsamındaki sigortalılığı esas alınanlar, yazılı talepte bulunmak ve Kanunun 82 nci maddesine göre belirlenen prime esas kazanç alt sınırı ve üst sınırına ilișkin hükümler saklı olmak kaydıyla, esas alınmayan sigortalılık statüsü kapsamında talep tarihinden itibaren prim ödeyebilirler. Bu şekilde ödenen primler; iş kazası ve meslek hastalığı sigortasından sağlanan haklar yönünden, Kanunun 4 üncü maddesinin birinci fikrasının (b) bendi kapsamında sigortalllık statüsünde, kısa vadeli sigorta kollarından sağlanan diğer yardımlar ile uzun vadeli sigorta kollarından sağlanan yardımlar yönünden ise Kanunun 4 üncü maddesinin birinci fikrasının (a) bendi kapsamında sigortalılık statüsünde değerlendirilir. (5510 SK, md. 53)
} 
(c) bendi (4/c) kapsamında sigortalı sayılan bir kişi dernekte ücretle iş ifa etse dahi 5510 sayılı Kanun'un 53 üncü maddesinde değinilen kural gereğince 4/a değil 4/c kapsamında sigortalı olabilecektir ve 4/a kapsamındaki sigortalılığ tercih etme gibi bir inisiyatifi bulunmayacaktır. Dolayısıyla bu durumda sigortalılığın önceliği veya baskınlığına bakılmaksızın 4/c kapsamında sigortalılık söz konusu olacaktır. Bunun nedeni, devlet memurunun esas itibariyle başka bir işte çalışma yasağının olması ve bu kişilerin aynı zamanda başka bir zorunlu sigortalılığının kural olarak mümkün olmamasıdır (Güzel, Okur ve Caniklioğlu, 2018, s.174).

Dernek yöneticisi tarafından üçüncü bir kişi tarafindan yapılabilecek işin ifa edilmesi ve karşıllı̆ında da ücret alınması ve söz konusu yöneticinin ayrıca Kanun'un 5 inci maddesi uyarınca bazı sigorta kollarına tabi olacak şekilde sigortalılığının bulunması veya isteğe bağlı sigortalı olması halinde ise 4/a kapsamında sigortalı sayılması ve diğer sigortalılık durumlarının iptal edilmesi gerekmektedir.

Son olarak belirtmek gerekir ki dernek yöneticisi tarafından üçüncü bir kişi tarafindan yapılabilecek işin ifa edilmesi ve karşılığında da ücret alınması durumuyla birlikte 4/a kapsamında sigortalı sayılma halinde prim ödeme yükümlüsü ve dolayısıyla bildirim yükümlüsü dernek tüzel kişiliği olacaktır. Dernek tüzel kişiliğinin yapmayacağı bildirimler nedeniyle uygulanacak idari para cezaları ve ödenmeyen primler ile gecikme zammı ve gecikme cezasından dernek tüzel kişiliği sorumlu olacaktır.

\section{GENEL OLARAK GÜVENİ KÖTÜYE KULLANMA SUÇU}

Hukuk sistemimizde güveni kötüye kullanma suçu 5237 sayılı Türk Ceza Kanunu'nun ${ }^{13} 155$ inci maddesinde düzenlenmiştir. 5237 sayılı Kanun m. 155/1'de suçun basit şekli, m. 155/2'de ise nitelikli şekli yer almaktadır. Söz konusu düzenlemeye göre;

"Başkasına ait olup da, muhafaza etmek veya belirli bir şekilde kullanmak üzere zilyedliği kendisine devredilmiş olan mal üzerinde, kendisinin veya başkasının yararına olarak, zilyedliğin devri amacı dışında tasarrufta bulunan veya bu devir olgusunu inkar eden kişi, şikayet üzerine, altı aydan iki yıla kadar hapis ve adlî para cezası ile cezalandirllır.

Suçun, meslek ve sanat, ticaret veya hizmet iliş̧kisinin ya da hangi nedenden doğmuş olursa olsun, başkasının mallarını idare etmek yetkisinin gereği olarak tevdi ve teslim edilmiş eşya hakkinda işlenmesi halinde, bir yıldan yedi yıla kadar hapis ve üçbin güne kadar adlî para cezasina hükmolunur."'14

Güveni kötüye kullanma suçu ile korunan hukuki değer öncelikle malvarlığı haklarıdır ve burada, malın sahibi veya fer'i zilyedi tarafindan malın başka bir kişiye karşılıklı güvene dayanarak teslim edilmesi ile bu kişinin malın sahibi ya da önceki fer'i zilyedinin iradesi dışında mal üzerinde tasarrufta bulunması söz konusudur (Merakl1, 2009, s. 1665).

Kanun'da yer alan ifadeye göre güveni kötüye kullanma suçunun unsurlarını şöyle sıralayabiliriz;

- Başkasına ait olup da, muhafaza etmek veya belirli bir şekilde kullanmak üzere zilyetliği kendisine devredilmiş olan mal bulunmalıdır. Zilyetliğin devri değil de mülkiyet devri söz konusu olursa güveni kötüye kullanma suçu söz konusu olmayacaktır (Meraklı, 2009, s. 1677).

- Malın zilyetliğinin mutlaka malik tarafından devredilmesi zorunlu olmayıp, zilyetliği faile devreden kimse, fail inkar etmediği sürece, kendisi de dolaylı zilyet kalmaya devam edecektir (Aytekin İnceoğlu, 2018, s. 44).

- Mal kişi tarafından kendisinin veya başkasının yararına olarak kullanılmalıdır.

- Güveni kötüye kullanma suçu ortaya somut bir zarar neticesi çıkmasa dahi oluşacaktır (Meraklı, 2009, s. 1711).

- Mal, zilyetliğin devri amacı dışında tasarrufta bulunan veya bu devir olgusunu inkar eden kişi tarafindan kullanılmalıdır.

\footnotetext{
13 Yayımlandığ1 Resmi Gazete: Tarih: 12/10/2004 Sayı:25611

14 Güveni kötüye kullanma suçu tamamlandıktan sonra ve fakat bu nedenle hakkında kovuşturma başlamadan önce, failin, azmettirenin veya yardım edenin bizzat pişmanlık göstererek mağdurun uğradı̆̆1 zararı aynen geri verme veya tazmin suretiyle tamamen gidermesi halinde, verilecek cezanın üçte ikisine kadarı indirilir. (5237 SK, md.168)
} 
- Zilyetliğin devri amacı dışında tasarrufta bulunma veya devir olgusunun inkar etme fiillerinin gerçekleşmesi ile birlikte güveni kötüye kullanma suçu tamamlanmakta olup, bunun dışında bir sonucun gerçekleşmesine gerek bulunmamaktadır (Koca ve Üzülmez, 2017, s. 638).

- Bu suç seçimlik hareketli bir suçtur ve Kanun'da yazılı olan hareketlerin bir ya da birkaçının ișlenmesi ile oluşur (Dönmez Hukuk Bürosu, 2017, s. 46).

- Suçun oluşumu için resmi bir görevlendirmeye gerek yoktur. Görevlendirmenin adli ya da diğer kamu organlarınca yapılması halinde güveni kötüye kullanma suçu değil, 5237 sayılı Kanun’un 289 uncu maddesi gereğince muhafaza görevini kötüye kullanma suçu oluşacaktır (Sümer, 2008, s. 112).

- Suçun nitelikli halinde ise, suç, meslek ve sanat, ticaret veya hizmet ilişkisinin ya da hangi nedenden doğmuş olursa olsun, başkasının mallarını idare etmek yetkisinin gereği olarak tevdi ve teslim edilmiş eşya hakkında işlenmelidir.

Güveni kötüye kullanma suçunun konusunu oluşturan malın maddi bir varlığa sahip olmas1 gerektiğinden alacaklar ve maddi varlığ bulunmayan diğer haklar bu suçun konusunu oluşturmayacaktır (Meraklı, 2009, s. 1669). Ayrıca eşyanın misli veya gayri misli olmasının suçun oluşması açısından bir önemi bulunmamaktadır (Koca ve Üzülmez, 2017, s. 631).

Güveni kötüye kullanma suçunun faili bu suçun konusunu oluşturan malın zilyetliğinin devredildiği kişi; mağduru ise, malın maliki ya da zilyedinden malın zilyetliğini devralan ve bu malı muhafaza etmesi veya belirli bir şekilde kullanması amacıyla bir başkasına zilyetliği devreden kişidir (Meraklı, 2009, s. 1682). Güveni kötüye kullanma suçunda, mağdurun iradesinin dışına çıkılmaktadır (Tüysüz, 2017, s. 116). Ayrıca mağdurun bu malların varlı̆̆ını bilmesi halinde bu mallar üzerindeki tasarruflar da güveni kötüye kullanma suçunu teşkil edecektir (Koca ve Üzülmez, 2017, s. 632).

\section{DERNEK FAALIYETINDEN KAYNAKLANAN GÜVENİ KÖTÜYE KULLANMA SUÇU VE SOSYAL GÜVENLİK İKILLEI}

Yukarıda bahsettiğimiz güveni kötüye kullanma suçunun 5253 sayılı Dernekler Kanunu'nda özel bir şekli düzenlenmiştir. Kanunun 32 nci maddesinin birinci fikrasının (f) bendine göre; "Her ne suretle olursa olsun kendisine tevdi olunan derneğe ait para veya para hükmündeki evrak, senet veya sair mallar kendisinin veya başkasının menfaatine olarak sarf veya istihlâk veya rehneden veya satan, gizleyen, imha, inkâr, tahrif veya tağyir eden yönetim kurulu başkanı ve üyeleri veya denetçiler ile derneğin diğer personeli Türk Ceza Kanununun güveni kötüye kullanma suçuna ilişkin hükümlerine göre cezalandirllır. Ayrıca, mahkeme yargılama sırasında sanıkların, organlardaki görevlerinden geçici olarak uzaklaştırılmasina da karar verebilir."

Söz konusu Kanun hükmüne göre, güveni kötüye kullanma suçunun oluşabilmesi için;

- Failin bir malın zilyedi olmas1,

- Malın iade edilmek veya belirli bir şekilde kullanmak üzere faile rızayla tevdi ve teslim edilmesi,

- Failin kendisine verilen malı, veriliş gayesinin dışında, zilyedi olduğu malda malikmiş gibi satmas1, rehnetmesi, tüketmesi, değiştirmesi veya bozması ve benzeri şekillerde tasarrufta bulunması ya da devir olgusunu inkar etmesi şeklinde, kendisine veya başkasına yarar sağlaması gerekmektedir ${ }^{15}$.

Yukarıda açıkladığımız dernek yöneticilerine ilişkin güveni kötüye kullanma suçuna ilişkin bazı tartışmalı hususlar bulunmaktadır. Özellikle dernek yönetiminde bulunan kişilerin, üçüncü kişilerin yapabileceği bazı işleri yapmaları ve karşılığında ücret vb. adlar altında para almaları durumunda 5253 Sayılı Kanun 32/f maddesi uyarınca güveni kötüye kullanma suçunun ortaya çıkıp çıkmadığı hususu, üzerinde durulması gereken bir durumdur. Nitekim ülkemizde birçok dernekte bu tür ödemeler yapılmakta, İçişleri Bakanlığı Sivil Toplumla İlişkiler Genel Müdürlüğü tarafindan dernek denetçileri vasitasıyla yapılan denetimlerde de buna ilişkin hususlar tespit edilmektedir. Bu denetimler rutin şekilde yapılabileceği gibi ihbar veya şikayet üzerine de yapılabilmektedir (İçişleri Bakanlığı, 2019, s. 3). Gerekli görülen hallerde, derneklerin tüzüklerinde gösterilen amaçlar doğrultusunda faaliyet gösterip göstermedikleri, defterlerini ve kayıtlarını mevzuata uygun olarak tutup tutmadıkları İçişleri Bakanlığı

15 Yrg. 15. CD’nin, E. 2012/17063, K. 2014/9316 sayll Karar1; Yrg. 15. CD’nin, E. 2012/16448, K. 2014/8289 sayll Kararı. 
veya mülki idare amirleri tarafından dış denetim şeklinde denetlenmektedir (Varon, 2019, s. 61). Yapılan bu denetimler neticesinde tespit edilen dernek yöneticilerine yapılan ödemeler 5253 Sayılı Kanun 32/f maddesi uyarınca güveni kötüye kullanma suçu olarak değerlendirilebilmekte ve sonucunda da savcılıklara suç duyurusunda bulunulmaktadır ${ }^{16}$.

Dernek yöneticilerinin dernekten ücret ve benzeri adlar altında aldıkları paraların gerek 5253 sayılı Kanun gerekse de sosyal güvenlik mevzuatı karşısındaki durumlarını ve sonuçlarını dört başlık altında inceleyip değerlendirmemiz mümkündür:

\section{a) Kamu görevlisi olmayan dernek yöneticisine dernek yöneticiliği nedeniyle ödeme yapılması}

Önceki başlıklarda da değinildiği üzere 5253 sayılı Kanun'un 13 üncü maddesine göre, dernek yönetim ve denetim kurullarının kamu görevlisi olmayan başkan ve üyelerine ücret verilebilmektedir. Dernekler Kanunu'nda bahsedilen ücretin, kamu görevlisi olmayan yönetim ve denetim kurulu üyelerine verilmesinden kasıt, hizmet akdi ile çalışmadan bahsedilmediği sadece yapmış oldukları görevden dolayı alınan ücretten bahsedildiğinin anlaşılması gerekmektedir (Kaymazlar, 2017, s. 289). Dolayısıyla yapılan bu tür ödemeler kanuna uygun olup herhangi bir sakınca dogurmamaktadır.

Bununla birlikte, dernek yöneticileri, bu görevlere seçimle geldiklerinden, dernekle aralarındaki hukuki ilişki vekalet akdine dayanmakta ve sosyal güvenlik mevzuatına göre (2013/11 sayılı Genelge) sigortalı sayılmamaktadır. Bu görevlerinden dolayı huzur hakkı veya sair bir ad altında ücret almaları da akdin niteliğini değiştirmeyecektir. Dolayısıyla dernek yöneticilerine yürüttükleri görev nedeniyle yapılacak ödemeler sigortalı sayılmalarını gerektirmeyecektir.

\section{b) Kamu görevlisi olan dernek yöneticisine dernek yöneticiliği nedeniyle ödeme yapılması}

5253 say1lı Kanun'un 13 üncü maddesinde belirtilen, dernek yöneticilerine bu görevleri nedeniyle ücret ödenebilmesi yönündeki serbestlikten kamu görevlisi olan yöneticiler hariç tutulmuşlardır. Bu sebeple kamu görevlisi olan dernek yöneticilerine ücret ödenmesi mümkün değildir. Ancak 5253 sayılı Kanun'un 13 üncü maddesinde yer alan bu kurala aykırı uygulamaların yaptırımı kanunda açık bir şekilde belirtilmemiştir (Yalçın ve Öz, 2011, s. 261). Dolayısıyla dernek tarafından kamu görevlisi olan yöneticiye ücret ödemesi yapılması halinde güveni kötüye kullanma suçu söz konusu olmayıp bir yaptırım da uygulanamayacaktır. Ancak bu hususla alakalı 657 sayılı Devlet Memurları Kanunu'nda yer alan başka işte çalışma yasağına ilişkin hükümlerin ayrıca değerlendirilmesi gerekmektedir ${ }^{17}$.

Kamu görevlisi olan dernek yöneticisine dernek yöneticiliği nedeniyle ödeme yapılması halinde sosyal güvenlik noktasında yukarıda kamu görevlisi olmayan yöneticiler için geçerli olan hususlar aynen geçerlidir ve bu durum sigortalılı̆̆ı gerektirmeyecektir. Ayrıca 5510 sayılı Kanun'un 53 üncü maddesinde düzenlenen ve önceki başlıklarda değindiğimiz sigortalılık çakışması kuralı gereğince 4/c kapsamındaki sosyal güvenlik statüsünün değişmesi zaten mümkün olmayacaktır.

\section{c) Kamu görevlisi olmayan dernek yöneticisine üçüncü kişilerin yapabileceği bir işi yapması nedeniyle ödeme yapılması}

Çalışma hayatı ile ilgili olarak mevzuata baktı̆̆ımızda en üst düzenleme olan Anayasamızın 18. maddesinde "Hiç kimse zorla çalıştırılamaz. Angarya yasaktır." denilmekte ve 55. maddesinde "Ücret emeğin karşılığıdır." denilerek çalışmanın genel hatları belirlenmiştir. Bunun yanında 5253 sayılı Kanun'un 13 üncü maddesinde, dernek hizmetleri gönüllüler veya yönetim kurulu kararı ile göreve başlatılan ücretliler aracıllğıyla yürütüleceği ve dernek hizmetleri için görevlendirilecek üyelere verilecek gündelik ve yolluk miktarlarının genel kurul tarafından tespit olunacağı belirtilmiştir. Söz konusu yasal düzenlemelerden de anlaşılacağı üzere dernek faaliyetlerinin bir ödeme yapılmak süratiyle dernek üyeleri tarafindan gerçekleştirilmesi mümkündür. Bu noktada dernek yöneticilerini kapsam dış1

\footnotetext{
16 Dernek vakıf yöneticileri ile ilgili güveni kötüye kullanma iddiaları hakkında her türlü şüpheden uzak, kesin ve inandırıcı deliller elde edilmeden hüküm verilmemesi gerektiği ile ilgili olarak, bkz: Yrg. 15. CD’nin, E. 2017/26450, K. 2018/393 say1l Kararı; Yrg. 15. CD'nin, E. 2014/17829, K. 2017/7141 sayılı Kararı; Yrg. 15. CD'nin, E. 2014/15079, K. 2017/6968 say1l Kararı.

17 Memurlar, mesleki faaliyette veya serbest meslek icrasinda bulunmak üzere ofis, büro, muayenehane ve benzeri yerler açamaz; gerçek kişilere, özel hukuk tüzel kişilerine veya kamu kurumu niteliğindeki meslek kuruluşlarına ait herhangi bir iş yerinde veya vakıf yükseköğretim kurumlarında çalışamaz. (657 SK, md. 28)
} 
bırakan bir hüküm de bulunmamaktadır. Dolayısıyla kamu görevlisi olmayan dernek yöneticisine üçüncü kişilerin yapabileceği bir işi yapması nedeniyle ödeme yapılması mevzuata aykırı değildir.

Çalışmamızın dernek yöneticilerinin sosyal güvenliği başlığında da ayrıntılı olarak incelendiği üzere, dernek yöneticileri, bu görevleri haricinde, hizmet akdine tabi olarak, üçüncü şahısların yapabilecekleri işleri yapmaları karşılığında ücret ödenmesi şartıyla 4/a kapsamında sigortalı sayılacaklardır.

\section{d) Kamu görevlisi olan dernek yöneticisine üçüncü kişilerin yapabileceği bir işi yapması nedeniyle ödeme yapılması}

5253 say1l Kanun'un 32/f maddesinde düzenlenen güveni kötüye kullanma suçunun özel haline ilişkin tereddüt oluşturan ve uyuşmazlıklara konu olan kısım, kamu görevlisi olan dernek yöneticilerinin üçüncü kişilerin yapabileceği bir işi yapması ve karşılığında değişik adlarla ödeme alması durumudur. Özellikle belli bir mesleğe sahip olan kamu görevlilerinin kurdukları derneklerde gerçekleștirilen eğitim, dergi ve kitap türü basın-yayın veya reklam bulma gibi faaliyetler sonucunda gerek üyelere gerekse de yöneticilere ücret, gündelik, telif ve benzeri adlarla ödemeler yapılabilmektedir. Yapılan bu ödemeler İçişleri Bakanlığı tarafından yapılan denetimlerde 5253 sayılı Kanun'un 32/f maddesi kapsamında değerlendirilebilmekte ve güveni kötüye kullanma suçu kapsamında savcıllğa suç duyurusunda bulunulmaktadır.

Yukarıda da değinildiği üzere 5253 sayılı Kanun'un 32/f maddesi kapsamında güveni kötüye kullanma suçunun oluşabilmesi için; failin bir malın zilyedi olması, malın iade edilmek veya belirli bir şekilde kullanmak üzere faile rızayla tevdi ve teslim edilmesi, failin kendisine verilen malı, veriliş gayesinin dışında, zilyedi olduğu malda malikmiş gibi satması, rehnetmesi, tüketmesi, değiştirmesi veya bozması ve benzeri şekillerde tasarrufta bulunması ya da devir olgusunu inkar etmesi şeklinde, kendisine veya başkasına yarar sağlaması gerekmektedir. Ancak kamu görevlisi olan dernek yöneticisine üçüncü kişilerin yapabileceği bir işi yapması nedeniyle ödeme yapılmasının bu kapsamda değerlendirilebilmesi mümkün değildir.

Nitekim Yargitay bir kararında, dernek yöneticisinin herhangi bir dernek genel kurulu veya yönetim kurulu kararı bulunmadığ 1 halde, dernek tarafindan mukabele okuma konusunda görevlendirildiği ve bu doğrultuda kendisine ödemede bulunulduğu, sanığın dernekten aldığı parayı, dernek başkanı veya yönetim kurulu üyesi olmasından dolayı almadığı, yapmış olduğu hizmetin karşıllğg olarak aldığı, bu duruma kanuni hiç bir engelin bulunmadığ belirtilmiş ve güveni kötüye kullanma durumunun söz konusu olmadığına karar verilmiştir ${ }^{18}$. Nitekim Devlet Personel Başkanlığı da dernek üyelerinin (yönetici ayrımı yapılmaksızın) derneğin eğitim faaliyetlerinde görev alabilecekleri ve karşılığında bir ödeme yapılmasının mümkün olduğu yönünde görüş bildirmiştir (DPB, 2013).

Kanaatimizce, yukarıda değindiğimiz Yargıtay kararına paralel olarak, ister kamu görevlisi olsun ister olmasın, dernek yöneticisinin yöneticilik faaliyeti dışında dernek faydasına gerçekleştirdiği bir faaliyet nedeniyle değişik adlar altında aldığı ödemelerin 5253 sayılı Kanun'un 32/f maddesi kapsamında değerlendirilmesi mümkün değildir. Söz konusu ödemelerin, derneğe ait dergide makale yazılması halinde telif ödemesi şeklinde yapılması, yine dergide hakemlik ve benzeri görevlerde bulunmas1 nedeniyle yapılması, verilen eğitim nedeniyle gündelik şeklinde yapılması, derneğin yayın organlarına reklam bulunması karşılığı pay alınması şeklinde yapılması konunun niteliğini değiştirmeyecektir ve güveni kötüye kullanma suçu söz konusu olmamalıdır. Ancak dernek yöneticilerinin bu tür hizmetleri yapmamalarına karşın yapmış gibi göstererek dernekten ödeme almaları durumunun 5253 sayılı Kanun'un 32/f maddesi kapsamında değerlendirilebileceği açıktır.

Kamu görevlisi olan dernek yöneticisine üçüncü kişilerin yapabileceği bir işi yapması nedeniyle ödeme yapılması halinde sosyal güvenlik açısından 5510 sayılı Kanun'un 53 üncü maddesinde düzenlenen ve önceki başlıklarda değindiğimiz sigortalılık çakışması kuralı gereğince devlet memuru olan kamu görevlileri için 4/c kapsamındaki sosyal güvenlik statüsünün değişmesi mümkün olmayacaktır.

Ancak kamu görevlisi kavramı geniş bir alana sahip olup sadece devlet memurlarını kapsamamaktadır. Nitekim geniş anlamda kamu görevlileri kavramı, kamu kesiminde çalışan herkesi kapsamaktadır ve

18 Yrg. 15. CD’nin, E. 2014/805, K. 2016/6528 sayll Kararı 
örneğin, cumhurbaşkanı, bakanlar, milletvekilleri, belediye başkanları, belediye meclis üyeleri, il genel meclisi üyeleri, ihtiyar meclisi üyeleri, muhtarlar, hâkimler, subaylar, doktorlar, öğretmenler, hizmetliler, KİT'lerde görevli işçiler kamu görevlileridir (Yıldırım, 2016, s. 31). Ayrıca 5237 sayılı Türk Ceza Kanunu'na göre de kamu görevlisi deyiminden; kamusal faaliyetin yürütülmesine atama veya seçilme yoluyla ya da herhangi bir surette sürekli, süreli veya geçici olarak katılan kişilerin anlaşılması gerekmektedir (5237 SK, md. 6/1-c). Bu açıdan bakıldığında, 5510 sayılı Kanuna göre 4/c kapsamında olmayıp 4/a kapsamında olan kamu görevlisi dernek yöneticisinin, üçüncü kişilerin yapabileceği bir işi hizmet akdiyle ve ücretle yapması halinde sigortalı sayılması ve dernekten de ayrica 4/a kapsamında sigortalı olarak bildirilmesi gerekmektedir. Bu durum, İçişleri Bakanlığı uygulamaları gereğince bu faaliyetlerin güveni kötüye kullanma olarak değerlendirilmesi ile Sosyal Güvenlik Kurumu uygulamaları gereğince sigortalı sayılması gerektiği yönünde değerlendirilmesi gereğince bir ikileme neden olmaktadır. Kanaatimizce yukarıda da değindiğimiz üzere, İçişleri Bakanlığı'nın yapmış olduğu denetimlerdeki bu şekildeki yaklaşımı hatalı olup bu tür faaliyetlerin güveni kötüye kullanma olarak nitelendirilmemesi gerekmektedir.

\section{SONUÇ}

Dernek kurma, Anayasa ile güvence altına alınmış kişisel haklar arasında yer almaktadır ve dernek kurma hakkında serbestlik ilkesi geçerlidir. Dernek yönetimi ibaresi ise dernek organlarından olan yönetim kurulu ve denetim kurulunu ifade etmekte olup söz konusu kurulların oluşumu, Türk Medeni Kanunu'nda düzenlenmiştir.

Dernek başkanları ile derneğin yönetim ve denetim kurullarına seçilenler, bu göreve seçimle geldiklerinden, aralarındaki hukuki ilişki de vekalet akdine dayandığından sigortalı sayılmamaktadırlar. Ancak dernek başkanları ile derneğin yönetim, denetim kurullarına seçilenler ve dernek üyeleri; bu görevleri haricinde, hizmet akdine tabi olarak, üçüncü şahısların yapabilecekleri işleri yapmaları karşıllı̆ında ücret ödenmesi şartıyla 4/a kapsamında sigortalı sayılmaktadırlar.

Hukuk sistemimizde güveni kötüye kullanma suçu 5237 sayılı Türk Ceza Kanunu'nun 155 inci maddesinde düzenlenmiş olup 5253 sayılı Dernekler Kanunu'nun 32/f maddesinde bu suçun özel bir şekli düzenlenmiştir. Söz konusu Kanun uyarınca İçişleri Bakanlığı Sivil Toplumla İlişkiler Genel Müdürlüğü bünyesindeki denetçiler vasıtasıyla denetimler yapılmaktadır. Dernek yöneticilerinin faaliyetleri sonucunda dernek bütçesinden yapılan ödemeler bazı denetimlerde güveni kötüye kullanma olarak nitelendirilmekte ve bu durum da yargıya taşınmaktadır. Söz konusu uyuşmazlıkların; kamu görevlisi olmayan dernek yöneticisine dernek yöneticiliği nedeniyle ödeme yapılması, kamu görevlisi olan dernek yöneticisine dernek yöneticiliği nedeniyle ödeme yapılması, kamu görevlisi olmayan dernek yöneticisine üçüncü kişilerin yapabileceği bir işi yapması nedeniyle ödeme yapılması ve kamu görevlisi olan dernek yöneticisine üçüncü kişilerin yapabileceği bir işi yapması nedeniyle ödeme yapılması şeklinde ayrı ayrı ele alınması gerekmektedir. Burada özellikle kamu görevlisi kavramının tayini ve yapılan ödemenin sebebi önem taşımaktadır. Kamu görevlisi deyiminden; kamusal faaliyetin yürütülmesine atama veya seçilme yoluyla ya da herhangi bir surette sürekli, süreli veya geçici olarak katılan kişilerin anlaşılması gerekmektedir.

Özellikle memur olmayan kamu görevlisi dernek yöneticilerinin üçüncü kişilerin yapabileceği bir işi yapmaları nedeniyle ödeme yapılması halinde İçişleri Bakanlığı uygulamaları gereğince bu faaliyetlerin güveni kötüye kullanma olarak değerlendirilmesi ile Sosyal Güvenlik Kurumu uygulamaları gereğince sigortalı sayılması gerektiği yönünde değerlendirilmesi bir ikileme ve tereddüte neden olmaktadır. Kanaatimizce, kamu görevlisi olan dernek yöneticilerine ücret ödenmesinin Dernekler Kanunu'nda yasaklanmasına karşın yaptırımının bulunmaması ve emsal Yargıtay kararları gereğince bu nitelikteki ödemelerin güveni kötüye kullanma suçu kapsamında nitelendirilmemesi gerekmektedir.

\section{KAYNAKÇA}

Aday, S (2017). Dernek çalışanlarının sigortalılığı. E-Yaklaşım Dergisi, 300.

Arıc1, K. (2015). Türk sosyal güvenlik hukuku. Ankara: Gazi Kitabevi. 
Aytekin İnceoğlu, A. (2018). Güveni kötüye kullanma suçu. Galatasaray Üniversitesi Hukuk Fakültesi Dergisi, 1(1), 41-85.

Benzer, M. (2018). Dernek üyelerinin sigortalılığı. Lebib Yalkn Mevzuat Dergisi, 172, 78-82.

DPB-Devlet Personel Başkanlığ1 (2013). 08/01/2013- 19348 Sayılı Görüş. 26.11 .2019 tarihinde http://www.dpb.gov.tr/tr-tr/gorus/baska-is-ve-ticaret-yasagi adresinden erişildi.

Dönmez Hukuk Bürosu (2017). Kütahya ticaret ve sanayi odasi hukuk müşavirliği bilgilendirme notları. Kütahya.

Ecer, H. (2017). Derneklerin kuruluşu ve tüzel kişilik kazanması. Dicle Üniversitesi Adalet Meslek Yüksekokulu Dicle Adalet Dergisi, 1(2), 20-46.

Güzel, A., Okur, A.R. ve Caniklioğlu, N. (2018). Sosyal güvenlik hukuku. İstanbul: Beta Yayınevi.

İçişleri Bakanlığı Sivil Toplumla İlişkiler Genel Müdürlüğü (2019). Dernek denetçileri denetim rehberi. Ankara.

Kaymazlar, E. (2017). Dernek yönetim ve denetim kurulu üyeleri derneklerde ve iktisadi işletmelerinde sigortalı olabilirler mi? vergisel açıdan değerlendirilmesi. E-Yaklaşım Dergisi, 189.

Koca, M. ve Üzülmez, İ. (2017). Türk ceza hukuku özel hükümler. Ankara: Adalet Yayınevi.

Meraklı, S. (2009). Güveni kötüye kullanma suçu. Dokuz Eylül Üniversitesi Hukuk Fakültesi Dergisi, 11(Özel Sayı 2009), 1657-1714.

Sosyal Güvenlik Kurumu, Emeklilik Hizmetleri Genel Müdürlügü. 2013/11 Sayılı Genelge. 18.11.2019 tarihinde https://kms.kaysis.gov.tr/Home/Kurum/22620739\#collapse5 adresinden erişildi.

Sümer, R. (2008). Muhafaza görevini kötüye kullanma suçu. TBB Dergisi, 75, 109-137.

Türk Dil Kurumu (2019). Güncel Türkçe sözlük. 18.11.2019 tarihinde https://sozluk.gov.tr adresinden erişildi.

Tüysüz, F. (2017). Dolandırıcılık suçu. Yayınlanmamış yüksek lisans tezi, Başkent Üniversitesi Sosyal Bilimler Enstitüsü, Kamu Hukuku Anabilim Dalı. Ankara.

Varon, L., Türker N., Ersen T. ve Aklar Z. (2019). Dernekler için yasal mevzuat rehberi. İstanbul: TÜSEV Yayınları.

Yalçın, A. ve Öz, Y. (2011). Sivil toplum örgütleri için hukuk rehberi. Ankara: Odak Yayın.

Yavuzyiğit, M.H. (1995). Dernekler ve demokrasi. Ankara Üniversitesi SBF Dergisi, 50(1), 415-439.

Yıldırım, R. (2016). İdare hukukuna giriş. Eskişehir: Anadolu Üniversitesi Yayınları. 